Österreichische Akademie der Wissenschaften / Austrian Academy of Sciences AAS WORKING PAPERS IN SOCIAL ANTHROPOLOGY

Volume 23

Frank J. Korom

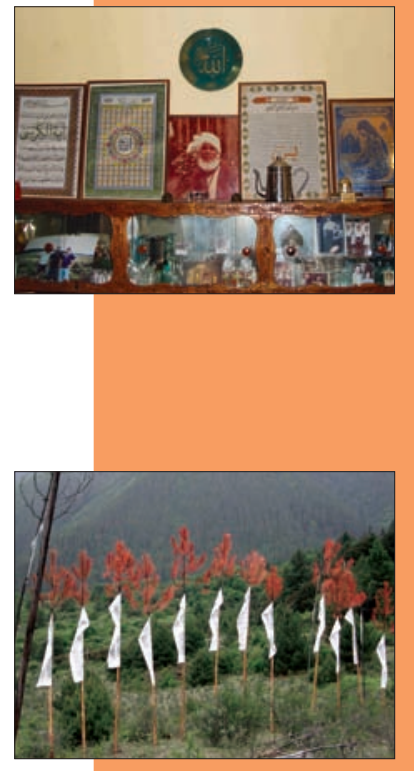

\title{
THE PRESENCE OF ABSENCE: USING STUFF IN A SOUTH ASIAN SUFI MOVEMENT
}

Band 23

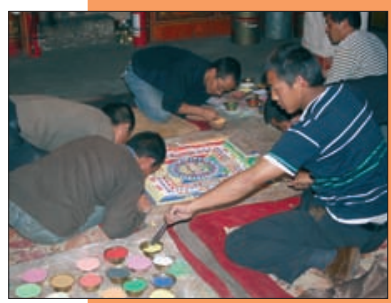




\section{AAS Working Papers in Social Anthropology / \\ ÖAW Arbeitspapiere zur Sozialanthropologie}

ISBN-Online: 978-3-7001-7257-4

doi:10.1553/wpsa23

Wien 2012

Editors / Herausgeber:

Andre Gingrich \& Guntram Hazod

(C) Institut für Sozialanthropologie

Zentrum Asienwissenschaften und Sozialanthropologie

Österreichische Akademie der Wissenschaften

Apostelgasse 23

A-1030 Wien

Fax: 01/ 51581-6450

E-Mail: sozialanthropologie@oeaw.ac.at 


\title{
THE PRESENCE OF ABSENCE: USING STUFF IN A CONTEMPORARY SOUTH ASIAN SUFI MOVEMENT*
}

\author{
FRANK J. KOROM
}

\begin{abstract}
:
The "presence of absence" here refers to a process by which a figure no longer physically in the world of lived reality is made manifest through the ritual use of stuff formerly belonging to or associated with the entity no longer present in the mundane realm, some of which may be termed relics. To develop this concept, I draw upon one contemporary Sufi group called the Bawa Muhaiyaddeen Fellowship, which has branches in the United States, Canada, and Sri Lanka, the place of origination of Bawa Muhaiyaddeen, a Tamil speaking saint who died in 1986, and is buried outside of Philadelphia. The study focuses on members' use of photographs of Bawa, sound recordings of his sermons, and items such as slippers he wore, chairs in which he sat, beds on which he slept, artwork he painted, and vegetarian recipes he prescribed to visualise and remember him constantly in the present. In so doing, it allows the community not only to "see" him but also to touch, smell, hear, and taste him. The argument assumes a form of "corpothetics," as Christopher Pinney has termed it, in which the entire sensorial range of the body is engaged in the process of practicing lived religion. This moves us beyond the now tired concept of auspicious sight (darśan) in South Asian religions to penetrate even deeper into how the entire range of the body's capacities are employed and engaged in the mystical process of making present that which is currently absent.
\end{abstract}

\section{Introduction}

In his essay “Why We Need Things," Mihaly Czikszentmihaly writes, "Every artifact is the product of human intentionality, but that intentionality itself is conditioned by the existence of previous objects" (1993: 21). In this sense, material culture embodies potentialities that are not necessarily in the control of creative human agency. They rather work reciprocally, for man-made objects can assume their own sense of volition once created. If we minimally define agency as "the capacity to effect changes in the external world" (Sax 2009: 93-94), then all things can have agency, not just individuals, but entire groups of people as well as non-human agents such as ghosts, machines, photographs, beds, clothes, and a vast variety of other such things. Czikszentmihaly further states that artifacts have symbiotic and/or parasitic relationships with human beings, thus creating both biophysical and psychological dependencies that enable the self to become stable in time and space (Ibid; cf. also Arendt 1958: 23). Moreover, one of the three functions of objects he identifies is to

\footnotetext{
* Research for this chapter has been supported by a grant from the American Institute for Sri Lankan Studies. Portions were read earlier at a workshop on Sufism in contemporary Sri Lanka, held in Colombo in November 2010 and at a Boston Consortium for South Asian Studies lecture in 2009. I wish to thank Dennis McGilvray, Ronit Ricci, and Torsten Tschacher for comments on earlier drafts, as well as Tracy Pintchman and Corinne Dempsey for pushing me to think comparatively about the role of saints and their remains. Discussions with Hilmy Mohideen and Mohammed Sahabdeen in Sri Lanka also proved very insightful, as have ongoing discussions with many members of the Fellowship too numerous to mention here spread out across the United States and Canada. Transliteration follows the standard Library of Congress system for foreign words in Arabic, Persian, Sanskrit, Tamil, and Urdu, but because many technical terms are loan words from Arabic and Persian into the South Asian vernaculars, the diacritical marks used herein depend on the context in which the terms are used.
} 
emplace the individual self within a broader social network of beings sharing relationships based on common values and concerns. They then collectively increase the symbolic capital (cf. Bourdieu 1984) of shared things by attributing value to them, as Patrick Geary (1978) has indicated in his study of relics in the context of post-Carolingian Europe, where he points out that objects associated with saints are passive and neutral until activated by people. As he writes, the symbolic function has to be assigned based on "its origin in the fabric of the society in which it was to be venerated" (Geary 1978: 7). A picture of a person, place, or thing, for example, can thus serve as an "icon of the past," and when viewed repeatedly anchors the individual temporally and spatially, providing permanence, so as to avoid "getting lost in the labyrinths of memory" (Czikszentmihaly 1993: 26).

The integral relationship of objects to selves is universally applicable from a psychological perspective, whether based on aesthetics or pragmatism, but becomes especially pertinent in the specific religious realm I wish to explore in this chapter. My basic contention is that through ongoing interaction with a range of representational objects, a class of which might be termed relic ( $\bar{a} t h \bar{a} r$ ), a community of like-minded individuals can maintain intimate contact with their spiritual guide decades after his exit from the mundane realm of existence. ${ }^{1}$ Stated another way, that which is physically absent can be rendered present through sensory interaction with things formerly belonging to or associated with the departed entity, in my particular case, a Sufi saint. Engaging in such dialectical practices with things allows members of the religious community in question to continue to make progress on their respective spiritual paths, while simultaneously drawing on his intercessory power. I refer to this phenomenon as the "presence of absence."

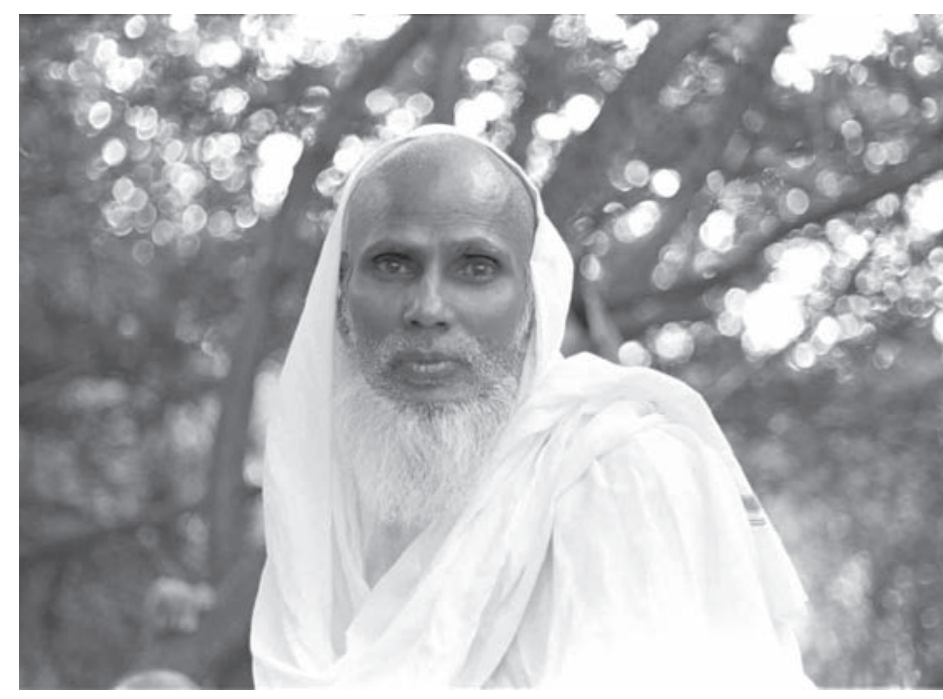

Figure 1:

The most widely circulated photograph of Muhammad Raheem Bawa Muhaiyaddeen (ral.) found in many homes, publications, and even annual ritual calendars distributed by the Fellowship. Notice the eyes, which are the source of much comment by people who knew him.

(Photo courtesy of the Bawa Muhaiyaddeen Fellowship)

To develop this concept, I wish to draw upon one contemporary Sufi group called the Bawa Muhaiyaddeen Fellowship, which has branches in the United States, Canada, and Sri Lanka, where the parent organisation is located under the Sri Lankan incorporated name Serendib Sufi Study Circle (SSSC). Although the birthplace of the founder is uncertain, the island nation is the place

\footnotetext{
${ }^{1}$ Walsham 2010 defines it as "a material object that relates to a particular individual and/or to events and places with which that individual was associated" (11). She also points out that "a relic is ontologically different from a representation or image" (12). However, she correctly acknowledges that the boundary between relics and representational images is permeable. I return to this issue in the concluding paragraphs of this chapter.
} 
where Muhammad Raheem Bawa Muhaiyaddeen (ral.), a Tamil speaking saint, began his public career. His birth date is not known but he died in 1986 and is buried outside of Philadelphia, Pennsylvania. ${ }^{2}$ I focus here on members' use of photographs of Bawa (see figures 1, 3, 5, 6), sound recordings of his sermons, as well as items such as slippers, sandals, and shoes he wore (see Figure 4); chairs in which he sat (see Figure 3), beds on which he slept (see Figure 6), artwork he painted (see Figure 5), and vegetarian recipes he prescribed to remember him constantly in the present by utilising the senses as vehicles for accomplishing an ongoing state of communication with the founder. In so doing, it allows the community not only to "see" him but also to touch, smell, hear, and taste him. In short, they feel his presence through repeated full body experiences. The argument assumes a form of "corpothetics" at play, in which the entire sensorial range of the body is engaged synaesthetically in the process of practicing lived religion (cf. Pinney 2004: 19). The emphasis on full bodily involvement allows us to move beyond the privileged concept of auspicious sight (darśan) in South Asian religions to penetrate even deeper into how the entire range of the body's capacities are employed and engaged in the mystical processes that, in this case, make present that which is currently absent. ${ }^{3}$ In so doing, I am not so much concerned with stuff's aesthetic nature (see, however, the lovely Figure 5) but share with Christopher Pinney the desire to explore the question what it does (Ibid.: 8). Before delving deeper into the sensual realm, it will be useful to provide some background to understand the emergence and establishment of the Fellowship as well as the context for current beliefs and practices.

\section{A Brief History of the Guru Bawa Movement}

According to oral history, sometime between 1940 and 1942, a Muslim holy man emerged from the jungles of southeastern Sri Lanka, in or near the pilgrimage site of Kataragama, which is sacred to Hindus, Buddhists, and Muslims, albeit for different reasons (cf. Obeyesekere 1977, 1978). He was a non-literate Tamil-speaking zindah pirr (living saint) of the Qadiri Sufi lineage (see Figure 2), although his affiliation to the order was quite limited and, perhaps intentionally, shrouded in

\footnotetext{
${ }^{2}$ Precious little exists by way of historical documentation of the figure in question, yet after conducting extensive fieldwork in both Sri Lanka and North America, during which oral histories have been collected, I personally believe he came to Sri Lanka from south India. Although I cannot elaborate here, a discussion is included in Korom 2011. Bawa goes by many titles, such as Guru, Shaikh, His Holiness, Teacher, Qutb, etc. Despite the fact that the title guru was dropped officially in 1973 (some sources say 1978) to dissociate from "charlatan" teachers of eastern spirituality, he is still widely known and referred to as Guru Bawa in Sri Lanka. It is customary within the group to refer to his full title at first usage, which I do, but he is referred to simply as Bawa thereafter. Bawa $(p \bar{a} v \bar{a})$ is the Tamil rendering of the Turkish $b \bar{a} b \bar{a}$, which means father in both a sacred and a secular sense. The use of such a kinship term is also significant in the way his "children" relate to him, since he regularly and somewhat playfully referred to his followers as his "funny family."

${ }^{3}$ The academic study of darśan in the Hindu tradition received its biggest endorsement with the publication of Eck 1981, and has remained virtually unchallenged until quite recently. Vidal 2006 has argued that her use of the term conflates a broad range of ocular phenomena ranging from Vedic revelatory seeing to Hindi film spectatorship. For another oft-cited piece on what the author refers to as "visual interaction," see Babb 1981. Most of the literature suggests the phenomenon to be a Hindu one, yet one could viably argue that it is pan-Indian or Indic in nature. For example, see Scott 1991 for a discussion of the concept in Buddhist Sri Lanka. Very little attempt has been made to understand visuality in Islam generally and South Asian Islam specifically, but see George 2010 and Frembgen 2006 respectively for good beginnings. Lastly, for a groundbreaking study on the role of the senses in anthropological fieldwork, see Stoller 1989, and more recently Keane 2008.
} 
mystery. ${ }^{4}$ Virtually nothing is known about this individual prior to his emergence from the wilds. ${ }^{5}$ He eventually settled in the Jaffna area on the northern side of the island circa 1942, where he ministered from the home of an affluent family of his patrons to whomever required his services; however, his clientele were, by and large, impoverished low-caste Hindus at the outset who came to him mostly for pragmatic reasons. In 1952, he had acquired a dilapidated Dutch warehouse and opened an ásram or religious commune near which he cleared land and farmed to feed the multitude of people who sought him out. ${ }^{6}$ By that time, he was already known as Guru Bawa among his Hindu followers, a father figure equated with lack of ego, mind, and creed, what his Muslim admirers would later refer to as the insān kāmil, or prototypical "perfect man." As his fame as a healer, exorcist, and counselor spread, Muslim intellectuals and Theosophists residing in Colombo eventually sought out the saint and brought him to the city to start the Serendib Sufi Study Circle in 1962, which was officially incorporated by the Sri Lankan parliament on November 27, 1974, and still thrives today?

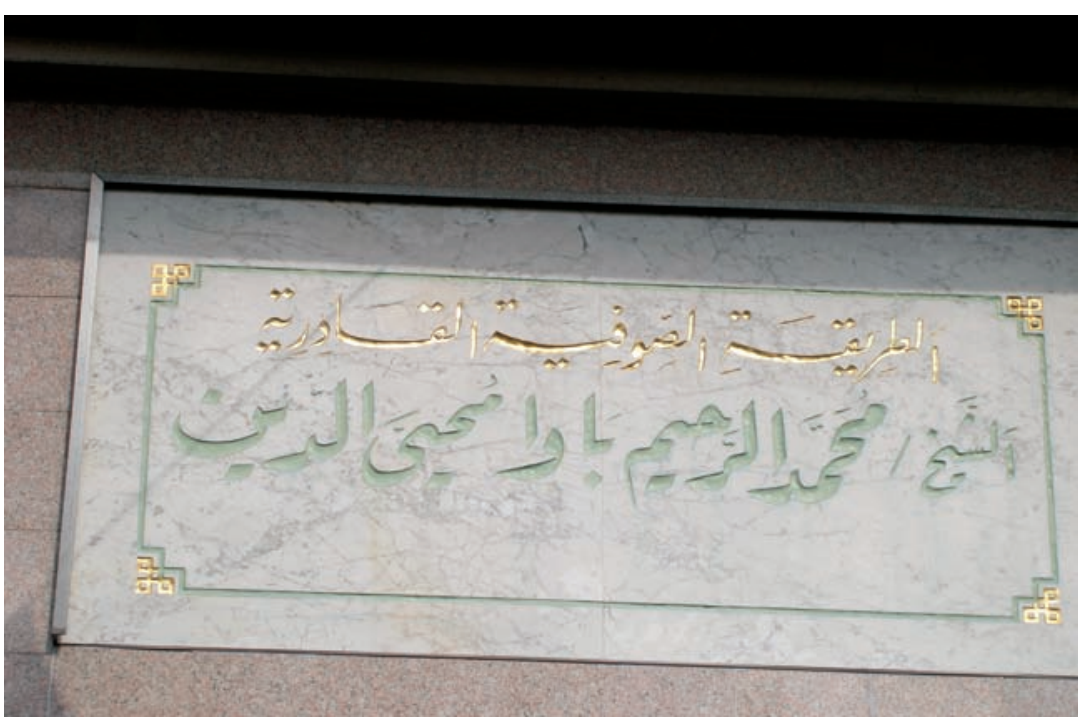

Figure 2:

A stone plaque engraved with Arabic calligraphy embedded above a threshold of Bawa's mosque in Philadelphia identifying it as belonging to the Qadiriyya in gold, under which is the name of the founder in green.

(Photo courtesy of the author)

\footnotetext{
${ }^{4}$ Nonetheless, the identification with Abdul Qadir Jilani, the "Saint of Baghdad," and his order is made quite explicit on the façade of the Fellowship's mosque in Philadelphia, where it is clearly written in etched gold leaf that it belongs to this order, as Figure 2 suggests. Bawa initially acknowledged the link, but in later years wouldn't discuss his own lineage because he felt such a question was a distraction, since it took people's minds of off God. Bawa repeatedly said that he came to the US at God's command. He also said that "God does God's work," which implies no self will on the part of individual actors doing the work on behalf of the movement. The movement is God's movement itself. See Mauroof 1976: 203-04. For an extremely useful introduction to the Sufi orders, see Trimingham 1971. On Jilani's significance and popularity in particular, see Padwick 1961: 240-42. For his importance in Sri Lanka specifically, see Aboosally 2002 and McGilvray 2004.

${ }^{5}$ Bawa rarely talked about himself, but his children did excavate some personal reminiscences from his many hours of audio and video recorded discourses to edit an autobiography titled The Tree That Fell To The West (Muhaiyaddeen 2003), which, however, reads more like a transcendental dialogue with God, unhindered by time and space, than an historical account of his life. As a self-styled hagiography, it is nonetheless a fascinating document. On the validity of hagiography in the historical enterprise, see Lifshitz 1994.

${ }^{6}$ In this sense, he very much fits the historical model of South Asian pirrs sketched by both Ansari 1992 in Sind and Eaton 1993 in Bengal.

${ }^{7}$ Incorporated under Law No. 41, Chapter 495 of 1974. Among the goals of the group are the following: the
} 
Half way around the world, a young American woman with a mystical bent had an unexpected experience in New Orleans during which a voice told her that time and space were one. As she later wrote in an appendix to one of Bawa's books,

I was alone, standing still in a detached mood. Things became visually very clear. Then everything seemed to be made up of dark colored dots, all in silence. Then it all disappeared. Everything. No sight, no sound, no smell, no touch, no body, nothing. Then through another kind of sight, seen as if looking at a movie, scenes appeared. It turned out that whatever was wished to be seen could be seen. Things in back of me, things miles away, whatever occurred to one to see, appeared (Muhaiyaddeen 1972: 249).

Then, suddenly, the silence of her void was pierced by the voice:

At some point, there began an awareness of a 'silent' voice explaining what was taking place. As the voice spoke, whatever it said became actuality. If it said something, that was what existed at that moment. Nothing else was, except the voice and the state that it explained. It was speaking very quickly, and many things simply can not [sic] be remembered (Ibid.).

For five years, the experience befuddled her, until she met a Sri Lankan man in 1968, who was a doctoral student at a university in Philadelphia. The student told the young but confused mystic numerous tales about his encounters with a sage named Bawa, as he is affectionately known, and she became enthralled with him and his perennial teachings. Shortly thereafter she began corresponding with the saint, who had by then hired a personal scribe and translator to whom he would dictate responses that were sent at regular intervals to this New Age seeker. In essence, it was spiritual counseling via airmail correspondence. During this period, she made preparations to sponsor a visit for him to Philadelphia by gathering like-minded spiritual seekers around her, who belonged to various racial, ethnic, and religious groups. Hence, in early 1971, she and her "fellowship" made final preparations to bring the teacher to the United States. To do this officially (i.e., to secure him a visa), she and a small core of his first devotees informally founded the Bawa Muhaiyaddeen Fellowship shortly before his arrival on October 11, 1971. ${ }^{8}$

The twenty-one people who met him at the airport collectively moved into a row home at 254 South 46th Street in West Philadelphia, where Bawa gave discourses every evening, after which he would feed the entire gathering with food cooked in the rented home's kitchen. Although he himself did not eat, food was very much an important part of the ongoing interactions with Bawa,

promotion and the study and understanding of Sufism (mysticism) among all persons seeking knowledge of Sufism, the compilation, translation, publication, and dissemination of the principles and practices of Sufism, establishment and maintenance of voluntary charitable organisations for, the purposes of, among others, relieving poverty, the care of widows and orphans, relief of hunger, disease and sickness, establishment of a scholarship fund for the higher study of Sufism, and the establishment of a center for the study and research into aspects of Sufism. This statement is paraphrased from the original incorporation document housed at the SSSC in Colombo. What the document makes clear, however, is that it focuses more exclusively on the works of His Holiness Sheikh Muhammed Muhiyadeen Guru Bawa, the fullest title used by the organisation, which incorporates many of the titles mentioned above in footnote 2 .

${ }^{8}$ The Commonwealth of Pennsylvania, Department of State Corporation Bureau approved non-profit corporation to the "Guru Bawa Fellowship of Philadelphia" on June 19, 1972, but allowed for the amending of the document on March 5, 1977 to change the name to the "Bawa Muhaiyaddeen Fellowship of Philadelphia." The mission statement in the 1972 document states that "This Fellowship is to pursue the Wisdom regarding the purpose of creation of the human species, the birth right of man and what the human man is doing now. The present conditions of the human specie $[s i c]$ and what will be his destiny. What is going to be his future?" 
and commensality continues to be a conspicuous part of Fellowship meetings and other sorts of gatherings. It is therefore not at all surprising that his favorite American holiday immediately became Thanksgiving, despite the fact that he advocated vegetarianism. In any case, by the fall of 1972 the group had drawn up a final charter for the organisation, in which Bawa mandated three presidents, three secretaries, and three treasurers to share corporate power, who are still among the sixteen members of the executive committee that assumed control of the Fellowship after the death of the founder. ${ }^{9}$

Known for his regular participation in interfaith dialogues, his infectious charisma drew in more and more people until the house could no longer accommodate the entire group. The Fellowship grew large and prosperous enough to purchase a former Jewish community center on the outskirts of the city in 1973 that was converted then into a Fellowship house where Bawa's "American family" could reside comfortably. The Fellowship was officially registered as a not-for-profit organisation in 1974. This event marks the third phase of the movement's institutionalisation, the first being the establishment of his a áram in northern Sri Lanka and the second being the founding of the Serendib Sufi Study Circle in Colombo.

A few years later, Bawa and his "children" began building a mosque on the Fellowship grounds that was completed and dedicated in May of 1984; it now serves as a multiethnic center of prayer and worship for immigrant Muslims as well as Bawa's American convert community. From the time he arrived in Philadelphia until his death on December 8, 1986, Bawa led a transnational existence, moving back and forth between his homeland in South Asia and his Fellowship house in Philadelphia. ${ }^{10}$ During the first trip back, he and forty-one of his American children built what he called God House in Mankumban, on Kayt's Island near the site of his original commune in Jaffna town, which is still in use today, having survived the incessant civil war that has plagued that portion of the island in recent decades. In fact, one story told repeatedly by Tamil villagers in the vicinity of God House is that when the Sri Lankan army attempted to occupy the site (thereby defiling it) after the expulsion of the Tamil Tiger rebels, Bawa intervened in the form of an albino snake to compel the soldiers to leave. ${ }^{11}$ Various raconteurs have embellished the core narrative of this apocryphal story over the previous months since the occupation to include entire hordes of snakes led by Bawa that victoriously drove the insensitive soldiers from the property.

During his last trip, Bawa fell into a coma and preparations for his funeral were being made when he suddenly awoke and proclaimed that Izrail, the archangel of death, had come to take him away, but he pleaded for more time to complete his mission on earth, according to eyewitness accounts. Purportedly granted pardon by the angel, Bawa returned to Philadelphia for the last time to spend

\footnotetext{
${ }^{9}$ However, Bawa made it clear that he retained the right to change any articles in the charter; hence, he established himself at the outset as a charismatic leader and as a bureaucrat with moral authority simultaneously.

${ }^{10}$ During his fifteen years in the United States, he returned to Sri Lanka four times (May 1972-February 1973; February 1974-July 1975; November 1976-August 1978; and December 1980-November 1982), always bringing along a retinue of his American "family" members with him. The times spent in Sri Lanka, approximately 5.8 years, constituted roughly $1 / 3$ of his entire transnational period.

${ }^{11}$ During my visit to Mankumban in July of 2010 and the subsequent months that followed, there were signs of revival and expansion within the commune and farm, which correspond to a general revivification of the Jaffna region since the end of the civil war some months earlier. The soldiers mentioned above, however, still remain encamped in a field across the road from God House, frequently visiting
} 
the remainder of his years preparing for his ultimate departure. His body now rests in a mazār (shrine) built for him by his followers in East Fallowfield township, located approximately forty miles outside of Philadelphia, on land purchased by the Fellowship years earlier in 1975 to serve as a Muslim cemetery and communal farm. The location, situated in a predominantly Baptist area of Chester County, has now become an international pilgrimage site and place of contemplation for visitors from South Asia and its diaspora, especially during Bawa's annual 'urs rituals held on the premises to commemorate his death anniversary. What started as a small group of dedicated seekers numbering 151 in 1972 grew exponentially in subsequent years. By 1976 the Fellowship boasted ten national and international centers and 7,000 members. Today rough estimates provided by Fellowship officials suggest that Bawa has approximately 10,000 children worldwide, with many more sympathisers. ${ }^{12}$

In summary, Bawa Muhaiyaddeen staged three "comings" during his career that loosely correspond to the stages of institutionalisation I described above. The first is his northern Sri Lankan phase, where he presented himself (or was presented) as a typical Hindu guru or Sufi shaikh, characterised primarily by pragmatism (i.e., farming, healing, settling disputes, etc.). The second phase sets in when he begins to minister to the elite of Colombo. This phase is more philosophical, tapping into a theosophical revivalist movement that was well under way in Sri Lanka by the 1970s, during which a variety of laymen and individual religious teachers without formal affiliations were beginning to preach and teach various forms of meditation (cf. Bond 2003). The third phase coincides with his arrival in the United States. Here he is first understood as the typical perennial mystic, so popular in early seventies' emergent New Age practice, which perpetuates universalism and anti-dogmatism. ${ }^{13}$ But gradually he comes to emphasise a distinct Islamic message that focuses on a fourfold spiritual developmental pattern. The progression moves from shari 'ah (revealed law), which involves discerning right from wrong and permissible behavior, to phase two, known as tarīqah (path), the strengthening of determination, to haqīqah (truth), the beginning of communication and union with God, leading finally to ma'rifah (gnosis), a more perfected state of union with God that ends up in șüfiyah, a state of constant remembrance (dhikr) and contemplation ( $f i k r)$ that transcends the "four religions," as defined by Bawa: Hinduism, Zoroastrianism, Christianity, Islam. ${ }^{14}$

the facilities to seek permission from the custodian to use the attached pilgrim rest house for their own personal use, which has thus far been unsuccessful. However, Shipmates consider the very fact that God House and the Jaffna commune remained unscathed during the civil war to be miraculous. For an excellent study of the Tamil speaking part of Sri Lanka and the consequences of war on the region, see McGilvray 2008.

${ }^{12}$ Mauroof 1976: 74. These numbers might be somewhat inflated, however, since one member showed me the Fellowship's directory, which contained approximately 1,000 names. However, the higher number might represent what can be called, à la Tweed 1992, "nightstand" Sufis, those sympathising with Bawa's teachings but not active or regular participants in Fellowship events. See also, Sedgwick 2009 for the ambiguous acceptance of Sufism in the West.

${ }^{13}$ On Sufism and the New Age, see Wilson 1998. Webb 2006 prefers to use the less loaded term "thirdwave." On the different portraits of him in these phases, Bawa himself said (circa 1930), "My appearance to the people who see me depends on how the various groups of them choose to view me.... The Muslims say that I am a Tamil swami. The Tamils [= Hindus] say that I am a Muslim swami,... The Christians say that I am a Tamil swami... In this manner each such group to whom I go, keep on ascribing names to me.... If there are any more such names, I am happy to have them" (Muhaiyaddeen 1988: i).

${ }^{14}$ On the stages of spiritual progress in Bawa's teachings, see Webb 1994. In this scheme, Buddhism is considered to be subsumed by Hinduism and Judaism by Islam. 
To understand Bawa's appeal truly, one must trace his historical development from his humble local roots in South Asia to his rise in international fame. When doing so, one notices a clear-cut move from a tolerant and non-denominational preacher toward a more structured founder of a religious lineage, which resulted in the development of this transnational spiritual movement from its local point of origin in the past to its global presence contemporaneously. It is only in this way that we can begin to appreciate how this unusual and somewhat anomalous individual's charisma led to the formation of an idiosyncratic Sufi community far removed from the founder's point of origin. The acclaimed sociologist Max Weber classically defined charisma as "a certain quality of an individual personality, by virtue of which he is set apart from ordinary men and treated as endowed with supernatural, superhuman, or at least specifically exceptional powers or qualities. These are such as are not accessible to the ordinary person, but are regarded as of divine origin or exemplary, and on the basis of them the individual concerned is treated as a leader" (Weber 1947: 358-59). Given this definition of charisma, it is not difficult to comprehend how Bawa eventually came to be regarded by his children and admirers as qutb, a lofty term reserved for the "pole-saint" or "pivot of the world," of which there is only one in each lifetime, and who occupies a unique place second only to the Prophet in the divine hierarchy of messengers and saints (Padwick 1961: 236). Indeed, Bawa often said that he easily could take the form of anyone, but he never took the Prophet's form, stating, "I have never gone in that form. None can go in that form. Accordingly, whatever form the supplicant seeks, that form is the one I use to go forth and give succour to, and come back" (Muhaiyaddeen 1988: iii).

As I understand it, we are now in the fourth stage of institutionalisation, during which the routinisation of charisma occurs. It is precisely after Bawa's death that what Weber terms the "charisma of office" is established (Weber 1947: 366), when Bawa's personally selected acolytes now become figures of authority responsible for maintaining and employing the saint's charisma through his Amt, or office, by creating stricter rules of belief and behavior, strengthening institutional infrastructure, and expanding membership by disseminating the founder's teachings through various forms of media, such as an aggressive publications programme and the launching of an official internet site..$^{15}$ All of these mundane concerns are, of course, economic necessities for the aspiring community to succeed, thrive, and grow in the absence of the founder. As Weber notes, charisma "must be adapted to some sort of fiscal organisation to provide for the needs of the group" (Ibid.: 369). It is in this fourth phase, in the absence of the founder, that the role of the senses becomes heightened to keep the memory of Bawa alive and, indeed, eternally present in the lifeworlds of his extended family on earth.

\section{Making Sense of Bawa}

So how does an unknown recluse from an obscure suburb of a town located on an island nation rise to fame and establish himself as a global authority on matters of the soul in a seemingly accidental or coincidental manner (despite the Fellowship's claim that nothing happens by chance) $?^{16}$ Moreover, what strategies did Bawa and his inner circle of students (= children) employ to manage his image

\footnotetext{
${ }^{15}$ For example, see Weber 1946; and for a valuable set of case studies about charisma within Sufi communities, see Werbner and Basu 1998.

${ }^{16}$ Fellowship members are fond and proud of pointing out that Bawa's interviews appeared in periodicals and newspapers such as Psychology Today and the Philadelphia Inquirer. They also highlight important talks he gave at prestigious places such as the United Nations and Harvard University, the latter of
} 
as he moved from Sri Lanka to the United States and gradually transitioned from an eclectic guru to a disciplined and normative Sufi shaikh who emphasised Islamic orthodoxy as a foundational platform for ultimately achieving a mystical state of gnosis? I would argue that central to this enterprise is an emphasis on the sensorium as a source for providing the means to stay attuned to Bawa's absent presence. Bawa himself was aware of the important role that the senses play in spiritual progress, and he spoke about it at length in some of his early discourses, to which I turn my attention in the next paragraph.

In one of the earliest translated compilations of his teachings published in 1971, Bawa dedicates a discussion to the sensory aspects of the individual's being that can either bring one closer to God or drive one away from Him. ${ }^{17}$ On hearing, he says, "allow only unto your audible senses only that which is of the Pure, and of Him, and of His angels and his Saints and you hear them hymn His praise in their worship and in their devotion to Him. And on hearing of these you yourself begin to follow suit and hymn His praise, in harmony with theirs" (Muhaiyaddeen 1971: 76). On sight, he says you must "be undisturbed in fixing your sight on Him alone, to see His eternal Beauty. For, within the light of that Supreme Certitude in His eternal Beauty, His unutterable mysteries, and His Love, you, the seeker, now experiences or sees Him, in supreme rapture, wonderment and unspeakable amasement, in harmony with theirs" (Ibid.). On smell, he encourages abandoning worldly odors for "the substitution of the living fragrance of His Messengers, His Prophets and Saints - so reminiscent of musk and incense in their subtle variations - these, you, the seeker, experience in complete wonderment" (Ibid.). On speech, "the Voice of God, and His utterances must be heeded, and with the tongue, you the seeker must direct your speech to him and hear His voice and so converse with Him, in the language of His Divine Praise" (Ibid.: 77). On taste, he says you must consume God's divine sustenance. "Chew with these teeth and savour of every morsel of it, realising how supremely wonderful is its taste..., you now chew and savour of the divine essence, swallowing it down in ecstasy" (Ibid.). These words were translated and published on the eve of Bawa's departure to the United States, where he would dedicate much of his time to cultivating the relationship between teacher and student, and to discussing the sixth, supreme sense that exists within the heart (qalb).

The above passages suggest a rather ambiguous function for the senses. On the one hand, they are to be negated as that which ties us to the mundane world $(d u n \bar{y} y \bar{a})$, yet on the other, they are the vehicle to achieve mystical union, liberation precisely from the material world..$^{18}$ The senses are, in other words, both the root of the problem and the solution to the problem. For Bawa, the process is essentially one of substituting the outer senses with the inner ones, or, better put, redirecting the outer toward the inner, where both sensoria can converge within the heart to achieve ecstatic union with the Creator. Yet, as he warns, "when we walk along the path to see Him, there may not even be space enough to walk let alone plant our step... To abandon the world for Him is difficult." (Ibid.: 78). For this reason, a need arises for a guide to show the way.

which was commemorated in 2009 by showing video recorded clips of his original talk at the very same venue by the Boston chapter of the Fellowship. For background, see Freudberg 1982-83.

${ }^{17}$ Only one printed source predates the one cited below, which is Kuru Mañ̄, or the teacher's jewel, a Tamil text published in 1961, it is based on a dictation made by Bawa to an unlettered goldsmith, who wrote it by hand as Bawa was dictating during the 1940s in Jaffna (most likely 1945, according to internal evidence within the document).

${ }^{18}$ In his discussion of remembrance, Bawa states: "What I am describing is not a prayer done through the senses or with the mind (emphasis added)." See Muhaiyaddeen 1999: back cover. 
In what is arguably one of his most widely read books titled Sheikh and Disciple (Muhaiyaddeen 1983), Bawa explicates the way a student should act toward his or her teacher. The student is subordinate to the teacher in every conceivable way, since it is the teacher who purposefully must mold the student from a shapeless hunk of clay into his own image. Nothing the shaikh does is random or arbitrary, so every glance, touch, or utterance has meaning (Ibid.: 16-17). In stating this, Bawa is evoking the senses of sight, touch, and sound. He is implying that the teacher comes to be known and understood subjectively through the sensual acts of seeing, touching, and hearing. One could also add smelling, as when the student takes in his perfumed scent while being in his presence during his lifetime or when breathing in his aroma in places where he is now thought to reside in his formless state. One could also taste him when consuming the vegetarian dishes that were among Bawa's favorite preparations, which he so lovingly cooked for all who attended his wisdom discourses. ${ }^{19}$ The teacher, in this sense, is a mirror, in which the student sees his own reflection and experiences his own self, for his goal is to make the children (i.e., students) like himself, thereby being in a constant state of union with the Divine (Ibid.: $31 \mathrm{ff}$ ). ${ }^{20}$

The senses therefore provide a vehicle to reject the fetters of the dunīy $\bar{a}$. But how is this abstract concept put into practice, even if sometimes unconscious, on a daily basis by members of the Fellowship? This question is particularly relevant today, a quarter of a century after the physical departure of the charismatic leader of what is also referred to colloquially as the Ship, a rather appropriate metaphor for symbolising the process of crossing over to the other side. One obvious way for practitioners to do this is through the sincere performance of dhikr, the oral or silent recitation of the first clause of the Muslim creed (shahädah), which proclaims that there is no god but God. But few, if any, would claim the ability to practice it constantly during the routine course of any given day. Other methods must thus be employed, which is precisely where the presence of absence idea makes good sense, so to speak. To conclude, I briefly provide some ethnographic examples and graphic illustrations of how the logic underlying the presence of absence works in the contemporary lives of Fellowship members, while also addressing the role played by relics in Islam more broadly construed.

\section{Conclusion: Things that Matter}

During the physical life of the teacher, the main way to gain the benefits of Bawa's wisdom was through his ontological presence. The goal of every one of his children was to spend as much time with him as possible, just to be in his presence to await his precious words, and in the meantime simply to gaze at him. As one Sri Lankan Buddhist admirer of Bawa told me in Negombo, "I would

\footnotetext{
${ }^{19}$ A common phenomenon reported by Bawa's children is his presence being felt by scent. American Fellowship members, for example, told me of smelling Bawa in the early hours of the morning at God House in Mankumban, and the president of the SSSC repeatedly asked me if I smelled Bawa during the weekly Sunday morning meetings in Colombo. Similar reports of olfactory incidents are common from his mosque and shrine in Pennsylvania, as well as in houses where he stayed during his years of sojourn. Many of these have shrine rooms dedicated to Bawa, as will be discussed below. As for meals, many cook food that was dear to Bawa, then reminisce how cooking and consuming food that pleased him is a way of remembering him in the present, which is ultimately an act of $d h i k r$, or remembrance. On Bawa's views concerning remembrance, see Muhaiyaddeen 1999.

${ }^{20}$ In fact, Bawa, borrowing from Ibn Arabi, often used the image of the mirror in his discourses (e.g., Muhaiyaddeen 1983: 75ff), inspiring the recent publication of reflections on him by the younger generation of his American family, who could be thought of as his grandchildren. See Le Pichon 2010. On the role and views of Fellowship youth, see the sympathetic study by Snyder 2003.
} 
go to his room [at the SSSC] after work each evening and sit in the corner to be with him. We did not talk much. I just sat and looked at him, but when he would look directly at me, I would lower my eyes out of reverential fear to avoid looking directly into his strong eyes (see Figure 1). He could see inside, you know. For me, it was comforting. It also helped me achieve my goals in life."21 While this individual was content to visit him daily, many Shipmates radically altered their lives to relocate to Philadelphia to be with him constantly, as virtually all of the conversion narratives I have collected attest. Some left school, others quit their jobs in order to devote all of their time to him, mostly out of a lingering concern that not being present even for one minute might lead to missing an utterance of wisdom (jñannam) emanating from his lips. One theatrical senior member of the inner circle told me in Philadelphia that she gave up her acting career to remain by Bawa's side because she was worried that she might not be there when something important happened. Another American woman in her late fifties also reminisced in Colombo while sitting on the floor in Bawa's former bedroom located in the SSSC, "We desired only to be in his presence. There was no desire to go out or to do anything else."22

The narrative told to me most often by Shipmates was giving up everything to be by his side, which meant being in his presence when awake, then sleeping at the feet of his bed or outside the door of his room when asleep. The only goal was to be in his presence: to see him, hear him giving wisdom discourses, touch him through various acts such as massaging his feet, hugging him, or holding his hand; and to smell him, which could be done even during his periodic absences by simply inhaling the odor emanating from the sheets on his bed or placing one's forehead on the sandals and slippers that he wore (see Figures 4,6). But all of this is easy while the master exists in his earthly body. The larger question pertaining to the continuity of his eternal presence, however, is how he continues to impact the lives of his extended family members from a transcendental realm

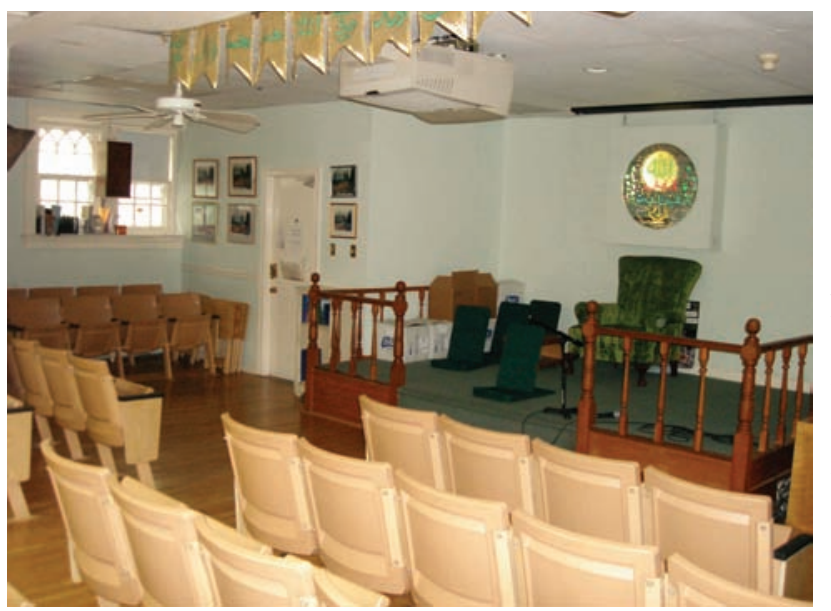

Figure 3:

Bawa's cushioned chair in green (his favorite color) on the pulpit at the front of the main meeting room in the Fellowship house, from which he used to give sermons on a regular basis. Today, no one ever sits in the chair, which serves as a symbol of his eternal presence. Instead, participants sit in the low floor seats visible in the foreground. Other members of the congregation sit in the wooden chairs facing the dais. Notice the photographs on the wall to the upper left, which adorn the entire building on all floors.

(Photo courtesy of the author)

\footnotetext{
${ }^{21}$ The person in question never gave up being a Buddhist, but considers Bawa to be a bodhisattva, or compassionate being who lives charitably for the sole purpose of alleviating the burdens of and spiritually aiding others. Field notes dated November 2010.

${ }^{22}$ Spoken by an inner circle member who had been with the saint ever since he landed in Philadelphia. This quote is from a conversation held in Colombo during her first return to the island since she was there with her teacher in 1985. Field notes dated August 2010. In fact, I have observed that many of Bawa's children take very little interest in Sri Lanka itself when they are there, preferring, rather, only to stay within the designated locations associated with Bawa's life and ministry, without straying too far to enjoy the tropical splendors of the island.
} 
that exists worlds beyond the mundane reality that the majority of us experience on a daily basis. ${ }^{23}$ How does one really make present that which is absent?

By all accounts, the immediate aftermath of Bawa's passing was a time of confusion and disarray. Numerous people told me quite frankly that they felt lost, since he to whom they were closest was no longer there with them in the corporeal sense. It took quite some time for the Shipmates to put their lives back in order and to adjust to Bawa's physical absence. One ex-member told me "they were like lost children" (Field notes 2009). However, things soon got back on track when methods were developed, some conscious, others unconscious, to feel his absent presence. One of the most common and ubiquitous techniques to do this both in North America and Sri Lanka continues to be gathering regularly, often on Sunday mornings, to listen to tapes of Bawa's numerous discourses, which are then followed by group discussions of the sermon electronically played to the audience in attendance. ${ }^{24}$ Mechanical reproduction therefore allows Bawa's words to continue to resonate even in his absence through the medium of tape recordings. It is within this very soundscape that Bawa's memory is preserved and contemplated to proceed further along the straight path. ${ }^{25}$

It can be argued viably that the most central public ritual of the Bawa Muhaiyaddeen Fellowship since the physical departure of its founder is the weekly Sunday morning meeting, be it in Colombo, Toronto, or Philadelphia. The normal course of such a session, as mentioned above, is the playing of a tape recording of Bawa's words concerning a particular topic, which is then followed by personal testimony and group discussion. This weekly event allows individuals to connect directly with Bawa through traces of his earthly presence in a room visually filled with his artwork, pictures of him, and, in Philadelphia, the cushioned chair in which he used to sit on a dais to speak to gatherings when he was still alive (see Figure 3). By "trace" here, I mean those things left behind that provide auras and mnemonic devices to assist the individual in remembering and connecting personally with Bawa through sensory means. ${ }^{26}$ By extension, then, personal connection is made social through group interaction with others who are in attendance and share the same worldview. Sensorial acts can thus be personal and communal simultaneously. This is why Czikszentmihaly (1993) says we need things, for they provide not only tangible continuity from the past to the present and the future, but also powerful means to connect the mundane to the transcendental.

\footnotetext{
${ }^{23}$ I intentionally use the cosmic vocabulary so common to members of the Fellowship to convey the sense of the transcendental that is very much a part of the everyday vocabulary of members of the community, especially when formal discourses are being given, such as during group meetings to discuss Bawa's teachings.

${ }^{24}$ Because Bawa said that God had given him only the capacity to speak in Tamil, he had a team of translators who provided constant simultaneous translation of his speech, virtually all of which was recorded either by audio or visual means. This repository of data is housed in an archive on the third floor of the Fellowship house in Philadelphia. It serves as the primary source material for generating books and pamphlets of Bawa's teachings, which are translated and edited by a committee of Fellowship members, then designed, typeset, printed, and bound in the Fellowship's own print shop located in the carriage house on the grounds of the Fellowship's residence and mosque.

${ }^{25}$ The concept of "soundscape" has developed out of the groundbreaking discussion by Appadurai concerning the various "scapes" that inhabit and shape modernity. See Appadurai 1996, especially pp. 48-65. For a good application of his concept to the acoustic realm, see Diehl 2002.

${ }^{26}$ After all, in the dictionary sense trace refers both to an indication of the existence or passing of something (for the inner circle) as well as to a physical change in the brain caused by a process involving learning (for the younger generation born after Bawa's death) and memory (for all Shipmates, young and old).
} 


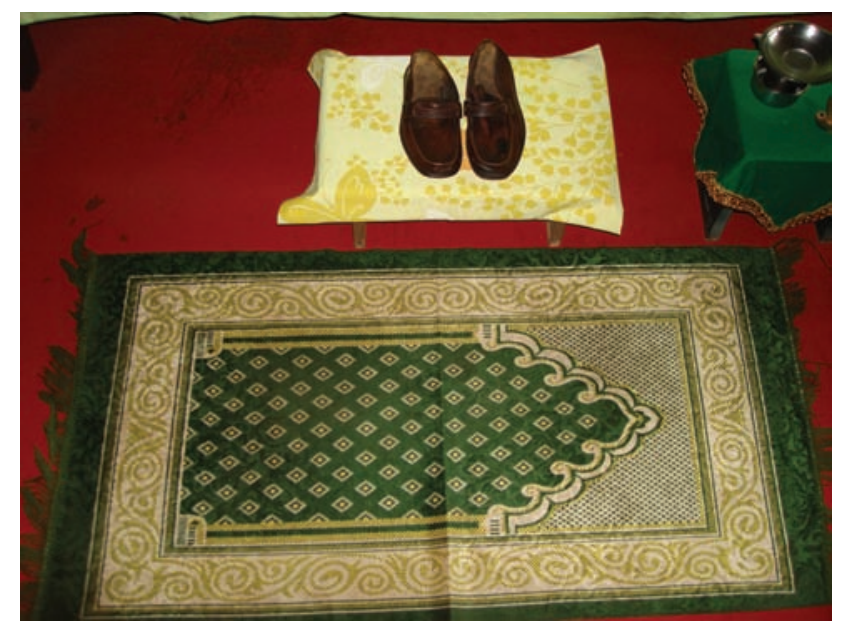

Figure 4:

A prayer rug and pair of Bawa's shoes on a pillow resting on a low wooden stool at the foot of one of his beds situated in his Jaffna āśram in northern Sri Lanka. To the right is a chalice of water for visitors to consume.

(Photo courtesy of the author)

Another such technique is reading aloud passages from Bawa's numerous publications, which often accompany the playing of tapes. I have witnessed intense emotional outbursts during such sessions, when individuals break down and cry, be they hardened bikers moved emotionally by his penetrating gaze (see Figure 1) or rational doctors inspired by his wise words. This heightened aspect of participation is an acute way of making Bawa present, especially for the second generation that was either too young to remember him or born after his death. ${ }^{27}$ In studying cassette sermons in Egypt, Charles Hirschkind (2001) has suggested that mechanical reproduction allows pious listeners to reconstruct their own moral personhoods along preconceived notions grounded in Islamic textual and practical traditions. So too do members of the Bawa Muhaiyaddeen Fellowship situate themselves within an imagined galaxy of global practitioners who share the common goal of imbibing in the experience of gnosis. ${ }^{28}$ The soundscape I have been describing is always accompanied by what we might call a scentscape and a tastescape resulting from the communal meal of vegetarian food cooked on the basis of Bawa's recipes in the adjacent kitchen, which offers his children, and now grandchildren, yet another way to reinforce his absent presence by reminiscing while eating about the way he used to feed everyone after lectures, even though he never ate himself. ${ }^{29}$

\footnotetext{
${ }^{27}$ This was made quite clear to me recently when I attended a silent $d h i k r$ ceremony at the Toronto chapter of the Fellowship in April of 2011. Youth who did not know Bawa in his own lifetime sat in an adjacent room listening to the adults in the other room reading from one of Bawa's books, intermittently weeping and smiling. When I spoke to some of the younger members later, they told me that they attend because their parents expect them to do so, but they have not yet fully absorbed the impact. One, however, mentioned that the level of commitment of the parents is what makes her want to learn more. Another college age child of an inner circle member who visited the Fellowship house frequently but did not live there told me in Boston that all he remembers of Bawa is receiving candy from him and being hugged afterward.

${ }^{28}$ Although the majority of Shipmates adhere solely to Bawa's teachings, a number can be considered to be Sufi shoppers, those who wish to advance spiritually within the broader Sufi traditions, without adhering too strictly to any one path. I have found this to be true in both North America and Sri Lanka. On the notion of the "spiritual marketplace," see Ellwood 1997.

${ }^{29}$ Many people mentioned his lack of caloric intake to me, considering it a miracle of his divine presence. Most testify that he never ate, but only took small sips of tea or water at the insistence of those offering it to him. Bawa mentions this himself in some of his own reminiscences. While visiting a saint's tomb in Akuressa, Sri Lanka, for example, he stated the following: "The food which they brought included beef curry, rice, a cup of milk tea, some sweetmeat.... They were watching me in my meditation....
} 
While the ethics of listening is essential to the communal experience of keeping Bawa's absence present, what happens when one is not within or amongst a group of his children? How does one keep Bawa's memory at the forefront when alone or within the confines of domestic intimacy? I asked this question in 2004 to one member of Bawa's inner circle who now lives far from Philadelphia in New Mexico, where no chapter of the Fellowship exists. She responded by looking around the living room of her home pointing at things that remind her of him constantly. Her quick and enthusiastic response resonates with what I have found generally to be true among Bawa's children, which is that they maintain and display a variety of things that always keep him within the reach of their sensorial radar. For example, things such as photos of him (see Figures $1 \& 5$ ), objects that once belonged to him (see Figure 3), books accredited to him, or reproductions of artwork (cf. Webb 1998) that he produced grace the homes and workspaces of Bawa's children. ${ }^{30}$ It is virtually impossible to enter the home of an individual who belongs to the group, without seeing some object associated with Bawa. Most common are framed photos of him that emphasise his piercing gaze (see figure 1), which one of his inner circle described to me as "x-ray vision," but also prominent are reproductions of his didactic paintings or other objects associated with him, such as items of clothing he wore or physical things with which he came in contact. ${ }^{31}$ Footwear representing his revered feet (pātam) is especially popular (see Figure 4) but reserved for places where he stayed regularly.

Unknowingly echoing the thoughts of the seventeenth-century Mughal prince Dara Shukoh on why some people need idols to worship (cf. Friedmann 1975: 217), the son of a woman who was with

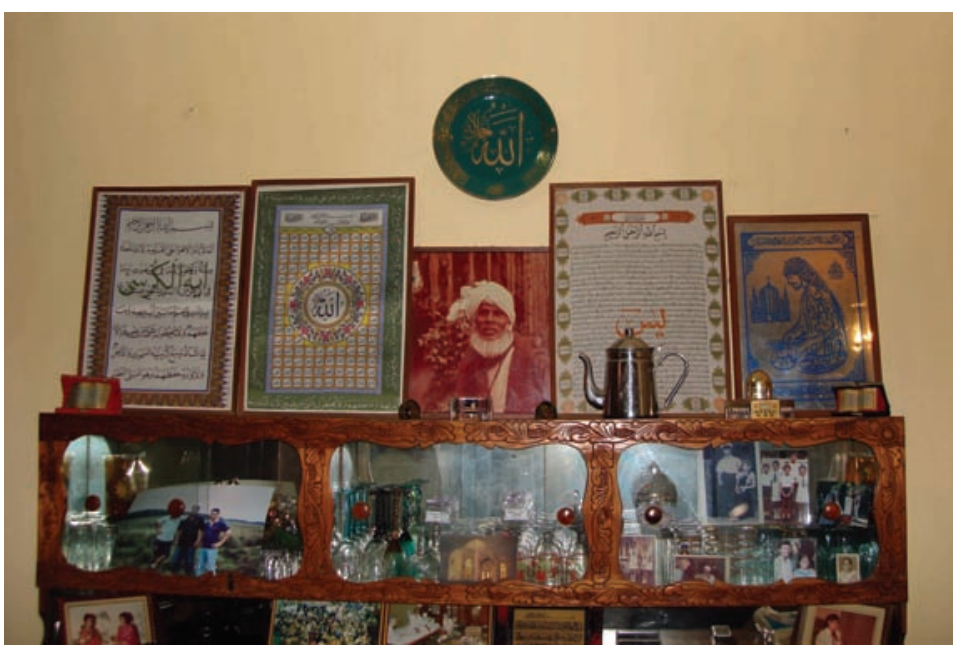

Figure 5:

A shrine cabinet aesthetically arranged in the living room of a Malay follower in Wattala, Sri Lanka displaying a photo of Bawa, reproductions of his artwork, blessed water for consumption by visitors, and other religious paraphernalia alongside family photos linking all of them to their spiritual father who hovers above them, and above him, Allah, represented by the calligraphic plate bearing His name hovering the highest. (Photo courtesy of the author)

All this while the food was there untouched. They took this food back to their houses.... They brought fresh food for the morning meal. This was also left untouched.... In the same way they removed this untouched food the next day morning. For three days this went on, the food remaining untouched" (Muhaiyaddeen 1988: vii). When asked how he managed to stay alive without eating, he typically replied that it was the grace of God.

${ }^{30}$ People in Sri Lanka constantly asked me for pictures of him or books by him, so as to make his absence present.

${ }^{31}$ One proud couple in Pennsylvania even has an embroidered calligraphic cloth (virippu) framed and hanging on their living room wall that once covered Bawa's tomb (ziyāram). The cloth on Bawa's tomb is changed annually during the 'urs, which on March 14, 2011 marked twenty-five years since his passing, attracting large crowds, including a Pakistani film crew, which was followed by a Sri Lankan style kantūri, a communal feast, for all in attendance. 
Bawa in Sri Lanka before he went to the United States told me one balmy day in October of 2010 that although Bawa was omnipresent, people needed "signs" of him, something they could latch on to, something tangible to demonstrate his ongoing presence, something to pray to or for, so that intervention might occur. In response to this, the president of the SSSC told me, "that is why they come and plead their cases here," referring to Bawa's room on the second floor of the organisation's building. Indeed, people go there regularly to offer petitionary prayer $\left(d u^{\prime} \bar{a}\right)$ in front of Bawa's bed, after which they touch it with their foreheads or touch the case containing his slippers with their right hand (see Figure 6). It is only through such sensory acts of reverence that the full benefit of Bawa's presence is actualised for many, and therein rests the purpose of representational objects. They allow us tangible means to connect with something unfathomable to the average human being. In the end, objects provide us a sense of certainty in a world fraught with uncertainty.

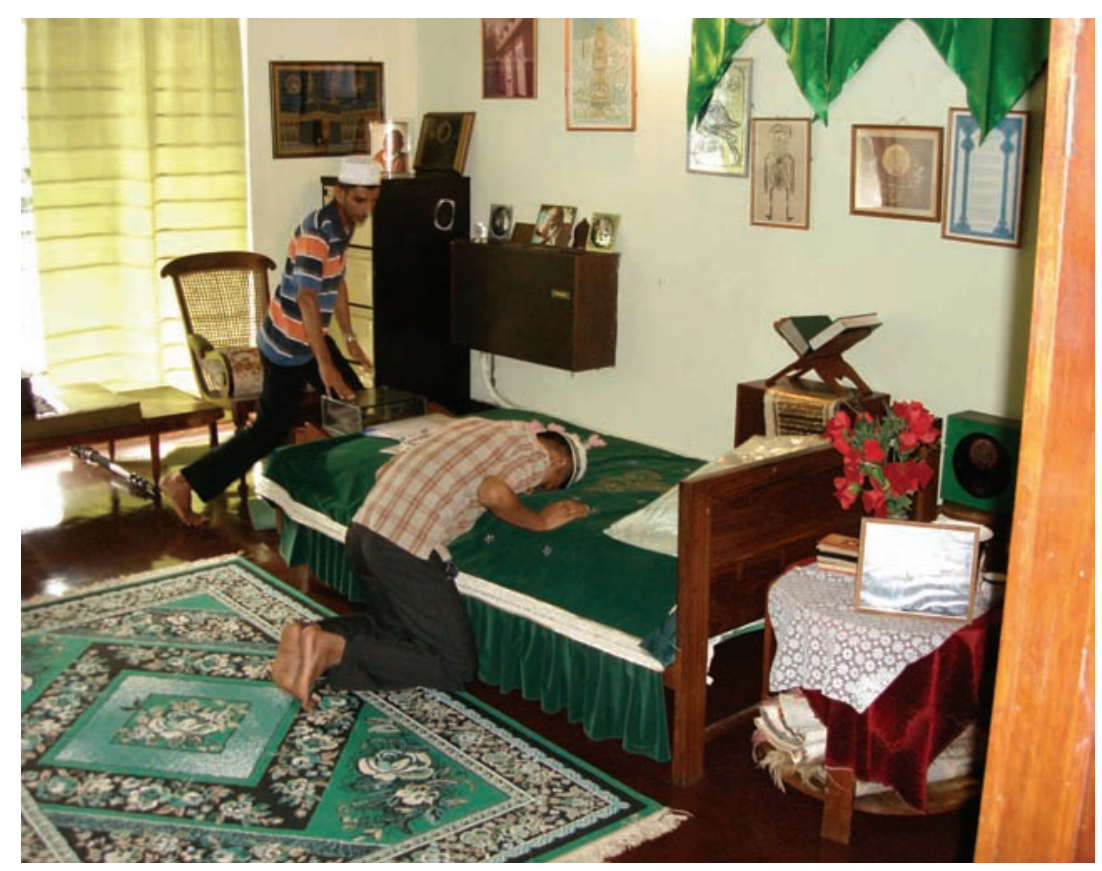

Figure 6:

Bawa's bed at the Serendib Sufi Study Circle in Colombo, Sri Lanka, where people go to "plead their cases" by performing $d u^{\prime} \bar{a}$, after which they touch their forehead to the bed's cover, kiss the pillow where his head rested, or touch the case at the foot of the bed containing his slippers, as these two young men are doing. Notice again the ubiquitous presence of Bawa's photos and artwork on the walls of his room.

(Photo courtesy of the author)

Indeed, it is in such contexts of uncertainty and fragmentation that historians of Christianity saw the most dramatic rise in the circulation of relics, to allow for the wall between the city of the living and the city of the dead to be breached by them, as Peter Brown (1981: 5) puts it. ${ }^{32}$ Yet he also suggests that the power of the "holy dead" never reached the zenith in Islam as it did in western European Catholicism (Ibid.: 10). ${ }^{33}$ Josef Meri (2010: 97-98) argues that this is not because of any paucity of sources but because of the inviolability and sanctity of the human body

${ }^{32}$ Another well-known historian of Christianity adds that in the absence of political protection and economic sustenance, people looked to saints for providing a "secure framework" to allow for doing the work of God (Geary 1978: 21). The legacy of saints thus continued after death through their material remains because they were "conduits of power" or "umbilical cords" that could communicate from beyond the grave (Walsham 2010: 13).

${ }^{33}$ Despite Brown's claim, European Islamicists did pay considerable attention to the phenomenon, but perhaps for the wrong reasons, as Ernst (1997: 8-18) has hinted. The seminal works of Goldziher, beginning in 1903, then 1911, and culminating in 1971 attest to this fact. Much more recently, there has been a resurgence of interest in the concept of corporeality among Sufis. See, for example, Bashir (2011) and Kugle (2007), who both elaborate on the saintly body as a locus of temporal and spiritual authority. 
in Islam. Human remains therefore circulated less than non-human objects that had come into contact with a saint. This is the case with Bawa. As we have seen, the objects associated with him are of two types: representational images and relics. Whereas the former are "indicators" of divine presence, the latter are actual "embodiments" of it, as Walsham (2010: 12) writes, "each particle encapsulating the essence of the departed person, pars pro toto, in its entirety." Even so, she goes on to say, relics and replicas should not be too sharply divided, for they both function as physical manifestations of the "act of remembrance" (Ibid.: 13), which I have described above as dhikr. Memory acts mediated by material things for Meri (2010: 99) provide the "deep spiritual connection the believer has with...the holy person to whom the relics belonged." Strikingly similar to the medieval Muslims about whom Meri is concerned, Bawa's contemporary followers wish to preserve their teacher's memory in objects symbolising the "tangible link between them and the holy person" (Ibid.). Sacred objects thus do matter because they are memorial links in the chain that connects past, present, and future in the Fellowship. Moreover, since they circulate within this tight knit community, they are catalysts for shared experiences of Bawa's continuous absent presence amongst them. Venerated objects, we can conclude, work both horizontally to connect people within specific social networks anchored in present time and space as well as vertically to link people across time and space. Crucial to such linkages is, of course, the experiential and ideological sharing of common aspirations, which for the members of the Fellowship amounts to one day being reunited with their teacher and their Maker on another plane of existence altogether after death.

Frank J. Korom is Professor of Anthropology and Religion at Boston University. He is the author and editor of eight books, most recently Village of Painters (2006) and South Asian Folklore (2006). His publications have focused primarily on South Asia and Tibet, as well as the diasporas originating from these regions. Most recently, he has been conducting fieldwork in Sri Lanka on Tamil Sufism, with a focus on Bawa Muhaiyaddeen and his circle of transnational followers. He is currently a resident fellow at the Clark Art Institute in Williamstown, MA, where he is completing a book tentatively titled Singing Modernity. 


\section{Literature}

Aboosally, M. L. M. 2002. Dafthar Jailany: A Historical Account of the Dafthar Jailany Rock Cave Mosque. Colombo: Dafthar Jailany Trust.

Ansari, Sarah. 1992. Sufi Saints and State Power: The Pirs of Sind, 1843-1947. Cambridge: Cambridge University Press.

Appadurai, Arjun. 1996. Modernity at Large: Cultural Dimensions of Globalization. Minneapolis: University of Minnesota Press.

Arendt, Hannah. 1958. The Human Condition. Chicago: University of Chicago Press.

Babb, Lawrence A. 1981. Glancing: Visual Interaction in Hinduism, Journal of Anthropological Research 37: 387-401.

Bashir, Shahzad. 2011. Sufi Bodies: Religion and Society in Medieval Islam. New York: Columbia University Press.

Bond, George D. 2003. The Contemporary Lay Meditation Movement and Lay Gurus in Sri Lanka, Religion 33(1): 23-55.

Bourdieu, Pierre. 1984. Distinction: A Social Critique of the Judgement of Taste. Cambridge, MA: Harvard University Press.

Brown, Peter. 1981. The Cult of the Saints: Its Rise and Function in Late Christianity. Chicago: University of Chicago Press.

Czikszentmihaly, Mihaly. 1993. Why We Need Things, in: Lubar, Steven and W. David Kingery (eds.). History from Things: Essays on Material Culture. Washington: Smithsonian Institution Press, 20-29.

Diehl, Keila. 2002. Echoes from Dharamsala: Music in the Life of a Tibetan Refugee Community. Berkeley: University of California Press.

Eaton, Richard M. 1993. The Rise of Islam on the Bengal Frontier, 1204-1760. Berkeley: University of Chicago Press.

Eck, Diana. 1981. Darśan: Seeing the Divine Image in India. Chambersburg, PA: Anima Books.

Ellwood, Robert S. 1997. The Fifties Spiritual Marketplace: American Religion in a Decade of Conflict. New Brunswick, NJ: Rutgers University Press.

Ernst, Carl W. 1997. Shambhala Guide to Sufism. Boston: Shambhala Publications, Inc.

Frembgen, Jürgen Wasim. 2006. The Friends of God: Popular Poster Art from Pakistan. Karachi: Oxford University Press.

Freudberg, David. 1982-83. Bawa Muhaiyaddeen: Inner \& Universal Meanings of Islam, Harvard Divinity Bulletin 13(2): 1-3.

Friedmann, Yohanan. 1975. Medieval Muslim Views of Indian Religions, Journal of the American Oriental Society 95(2): 214-21.

Geary, Patrick J. 1978. Furta Sacra: Thefts of Relics in the Central Middle Ages. Princeton, NJ: Princeton University Press.

George, Kenneth M. 2010. Picturing Islam: Art and Ethics in a Muslim Lifeworld. Malden, MA: Wiley-Blackwell.

Goldziher, Ignaz. 1971. Veneration of Saints in Islam, in: S. M. Stern (ed.), Muslim Studies. London: Allen and Unwin, 255-341.

Goldziher, Ignaz. 1911. The Cult of the Saints in Islam, Muslim World 1(3): 302-12. 
Goldziher, Ignácz (Ignaz). 1903. A Buddhismus hatásu as Islamra [The Influence of Buddhism on Islam]. Budapest: Magyar Tudományos Akadémia.

Hirschkind, Charles. 2001. The Aesthetics of Listening: Cassette-Sermon Audition in Contemporary Egypt, American Ethnologist 28(3): 623-49.

Keane, Webb. 2008. Evidence of the Senses and the Materiality of Religion, Journal of the Royal Anthropological Institute 14: 110-27.

Korom, Frank J. 2011. Charisma and Community: A Brief History of the Bawa Muhaiyaddeen Fellowship, Sri Lankan Journal of the Humanities 37(1-2): 19-33.

Kugle, Scott. 2007. Sufis \& Saints' Bodies: Mysticism, Corporeality, \& Sacred Power in Islam. Chapel Hill, NC: University of North Carolina Press.

Le Pichon, Chloë, et al. (eds.). 2010. The Mirror: Photographs and Reflections on Life with M. R. Bawa Muhaiyaddeen. Philadelphia: Privately published by the author.

Lifshitz, Felice. 1994. Beyond Positivism and Genre: 'Hagiographical' Texts as Historical Narrative, Viator 25: 95-113.

Mauroof, Mohamed. 1976. The Culture and Experience of Luminous and Liminal Komunesam. PhD Dissertation. Philadelphia: University of Pennsylvania.

McGilvray, Dennis B. 2008. Crucible of Conflict: Tamil and Muslim Society on the East Coast of Sri Lanka. Durham, NC: Duke University Press.

McGilvray, Dennis B. 2004. Jailani: A Sufi Shrine in Sri Lanka, in: Reifeld, Helmut and Imtiaz Ahmad (eds.), Lived Islam in South Asia: Adaptation, Accommodation and Conflict. Delhi: Social Science Press, 273-89.

Meri, Josef W. 2010. Relics of Piety and Power in Medieval Islam, in: Walsham, Alexandra (ed.), Relics and Remains, New York: Oxford University Press, 97-120.

Muhaiyaddeen, M. R. Bawa. 2003. The Tree That Fell To The West: Autobiography of a Sufi. Philadelphia: Fellowship Press.

Muhaiyaddeen, M. R. 1999. Dhikr: The Remembrance of God. Philadelphia: The Fellowship Press.

Muhaiyaddeen, M. R. Bawa. 1988. Wisdom of the Divine (Vol. 4.). Colombo: The Serendib Sufi Study Circle.

Muhayaiyaddeen, M. R. Bawa. 1983. Sheikh and Disciple. Philadelphia: The Fellowship Press.

Muhaiyaddeen, M. R. Bawa. 1972. The Divine Luminous Wisdom That Dispells the Darkness. Philadelphia: The Fellowship Press.

Muhaiyaddeen, M. R. Bawa. 1971. Wisdom of the Divine (Vol. I). Colombo: The Serendib Sufi Study Circle.

Obeyesekere, Gananath. 1977. Social Change and the Deities: The Rise of the Kataragama Cult in Modern Sri Lanka, Man 12(3-4): 377-96.

Obeyesekere, Gananath. 1978. The Fire-walkers of Kataragama: The Rise of Bhakti Religiosity in Buddhist Sri Lanka, Journal of Asian Studies 37(3): 457-76.

Padwick, Constance E. 1961. Muslim Devotions: A Study of Prayer Manuals in Common Use. Oxford: Oneworld Publications.

Pinney, Christopher. 2004. Photos of the Gods: The Printed Image and Political Struggle in India. London: Reaktion Press.

Sax, William S. 2009. God of Justice: Ritual Healing and Social Justice in the Central Himalayas. New York: Oxford University Press. 
Scott, David. 1991. The Cultural Poetics of Eyesight in Sri Lanka: Composure, Vulnerability, and the Singhala Concept of Distiya, Dialectical Anthropology 16: 85-102.

Sedgwick, Mark. 2009. The Reception of Sufi and neo-Sufi Literature, in: Geaves, Ron, Markus Dressler, and Grit Klinkhammer (eds.), Sufis in Western Society: Global Networking and Locality. New York: Routledge, 180-97.

Snyder, Benjamin H. 2003. Heartspace: The Bawa Muhaiyaddeen Fellowship and the Culture of Unity. BA Thesis. Phildelphia: Haverford College.

Stoller, Paul. 1989. The Taste of Ethnographic Things: The Senses in Anthropology. Philadelphia: University of Pennsylvania Press.

Tweed, Thomas A. 1992. The American Encounter with Buddhism 1884-1912: Victorian Culture and the Limits of Dissent. Bloomington: Indiana University Press.

Trimingham, J. Spencer. 1971. The Sufi Orders in Islam. Oxford: Clarendon Press.

Vidal, Denis. 2006. Darshan, in: School of Oriental and African Studies, University of London (ed.), South Asian Studies Keywords. At www.soas.ac.uk/southasianstudies/keywords/ file24803.pdf. Accessed on April 18, 2011.

Walsham, Alexandra. 2010. Introduction: Relics and Remains, in: Walsham, Alexandra (ed.), Relics and Remains. New York: Oxford University Press, 9-36.

Webb, Gisela. 2006. Third-wave Sufism in America and the Bawa Muhaiyaddeen Fellowship, in: Malik, Jamal and John Hinnells (eds.), Sufism in the West. New York: Routledge, 86-102.

Webb, Gisela. 1998. Teaching with Pictures: Three Paintings of Bawa Muhaiyaddeen, in: Renard, J. (ed.), Windows on the House of Islam. Berkeley: University of California Press, 290-96.

Webb, Gisela. 1994. Tradition and Innovation in Contemporary American Islamic Spirituality: The Bawa Muhaiyyaddeen Fellowship, in: Haddad, Yvonne Y. and Jane I. Smith (eds.), Muslim Communities in North America. Albany, NY: SUNY Press, 75-108.

Weber, Max. 1947. The Theory of Social and Economic Organization (trans. A. R Anderson and Talcott Parsons). New York: The Free Press.

Weber, Max. 1946. The Social Psychology of the World's Religions, in: From Max Weber: Essays in Sociology (trans, H. H. Gerth and C. Wright Mills). New York: Oxford University Press, 267-301.

Werbner, Pnina and Helene Basu (eds.) 1998. Embodying Charisma: Modernity, Locality and the Performance of Emotion in Sufi Cults. New York: Routledge.

Wilson, Peter. 1998. The Strange Fate of Sufism in the New Age, in: Peter B. Clarke (ed.), New Trends and Developments in the World of Islam, London: Luzac Oriental, 179-209. 